\title{
Efektifitas Pengelolaan Perpustakaan
}

\author{
Suyanik $^{1}$, Yatim Riyanto ${ }^{2}$, Soedjarwo ${ }^{3}$ \\ ${ }^{123}$ Surabaya State University \\ Email: suyanik.19017@mhs.unesa.ac.id
}

\begin{abstract}
The aim of the effectivenes of library mnajemen is to foster a culture of literacy, icrease the capacity of residents and the environment, as a fun and child-friendly learning park, maintain the continuity of learning by presentinga variety of reading books of accommodating various reading strategies. While the method used to callect observasional data. The ttechnique of sorting and analizing data in this activity uses quantitative research method were collected, grouped then presented in the form of quantitative, description. The data/resuts obtained (actual output) are divided by the target value.
\end{abstract}

Keywords: Effectiveness, Management, and Library

Abstrak. Tujuan Efektifitas pengeloaan perpustakaan untuk menumbuhkembangkan budaya literasi, meningkatkan kapasitas warga dan lingkungan, sebagai taman belajar yang menyenangkan dan ramah anak, menjaga keberlanjutan pembelajaran dengan menghadirkan beragam buku bacaan dan mewadahi berbagai strategi membaca. Sedangkan metode yang digunakan untuk mengumpulkan data dan informasi adalah Observasi. Teknik pengolahan dan analisis data dalam kegiatan ini menggunakan metode penelitian kuantitatif. Data yang di peroleh dikumpulkan, dikelompokan, kemudian, disajikan dalam bentuk deskripsi kuantitatif. Data/hasil yang diperoleh (output aktual) dibagi dengan nilai target.

Kata Kunci: Efektifitas, Pengelolaan, dan Perpustakaan

\section{PENDAHULUAN}

Perpustakaan merupakan salah satu unit pelaksana teknis yang dapat menunjukkan proses belajar mengajar. Dalam bidang pendidikan dan pengajaran, diupayakan bahan pustaka sesuai dengan kurikulum bersifat menambah wawasan pengetahuan, untuk mempertinggi hasil maupun untuk mempertinggi kualitas pendidikan di MINU Trate Putri Gresik.

Perpustakaan adalah pelayanan, tidak ada pelayanan jika tidak ada perpustakaan. Kegiatan melayani pembaca atau pemakai jasa perpustakaan secara tepat dan akurat disebut sebagai profesi pustakawan. Sementara itu, Indonesia juga membuat suatu aturan mengenai kewajiban seorang pengusaha penerbitan dan pengusaha rekaman untuk menyerahkan bukti karyanya pada perpustakaan. Dalam UndangUndang No.2 tahun 1989 tentang eksistensi perpustakaan yaitu pasal 35, disebutkan bahwa "setiap satuan pendidikan, jalur pendidikan sekolah yang diselenggarakan oleh pemerintah maupun masyarakat harus menyediakan sumber belajar". Pada penjelasan Undang-Undang No. 2 tahun 1989 tersebut juga dinyatakan bahwa pendidikan tidak mungkin terselenggara dengan baik apabila tenaga kependidikan maupun para peserta didik tidak didukung oleh sumber belajar yang diperlukan untuk penyelenggaraan kegiatan belajar mengajar yang bersangkutan.

Berbicara tentang perpustakaan bukan merupakan hal baru di kalangan masyarakat, dimana-mana diselenggarakan perpustakaan seperti perguruan tinggi, sekolah-sekolah baik sekolah umum maupun kejuruan, sekolah dasar maupun sekolah menengah. Begitu pula di kantor-kantor bahkan sekarang digalakkan perpustakaan-perpustakaan umum baik ditingkat kabupaten sampai ditingkat desa. Hal ini disebabkan oleh adanya informasi yang pesat dan membawa banyak perubahan pada semua sektor kehidupan dan telah mengantar kita ke arah kemajuan yang makin modern. Perubahan ini terjadi banyak dipengaruhi oleh pesatnya pertumbuhan ilmu pengetahuan disertai dengan berkembangnya teknologi canggih, untuk mengikuti perubahan tersebut diperlukan langkah yang cepat dan tepat untuk mendesain dengan baik segala bentuk informasi yang baru yang kemudian disebarkan kepada masyarakat pengguna demi terbentuknya pola pikir dan pola tingkah laku yang baru. 
Perpustakaan MINU Terate Putri Gresik tentunya memiliki berbagai macam koleksi baik yang berbentuk buku maupun non buku, koleksi tersebut dapat dilihat dari segi kepentingannya, pemanfaatannya, dan kebutuhan pemakainya. Semua koleksi tersebut perlu diolah sebelum disajikan kepada pemustaka. Pengolahan koleksi pada suatu perpustakaan dimaksudkan agar semua koleksi yang ada dapat dimanfaatkan dengan mudah oleh para pemakai perpustakaan. Untuk kegiatan pengolahan koleksi dapat dipikirkan supaya mekanisme yang menghubungkan koleksi sebagai media informasi dengan pembaca sesuai dengan disiplin ilmu yang diinginkan. Peranan ilmu pengetahuan dan teknologi sebagai sumber daya di dalam pendidikan penting, terutama dalam upaya meningkatkan mutu perpustakaan sangat dibutuhkan oleh pemustaka jasa perpustakaan, khususnya di lingkungan sekolah. Bahan-bahan pustaka yang tersedia di perpustakaan akan menimbulkan motivasi belajar.

Semakin sadar akan pentingnya pendidikan seiring dengan majunya perkembangan ilmu pengetahuan dan teknologi serta informasi, untuk mencapai maksud tersebut maka perlu meningkatkan pemanfaatan akan perpustakaan. Oleh karena itu, perlu mendapat perhatian dari pemerintah serta pihak pengelola perpustakaan itu sendiri.

Untuk menunjang tercapainya misi perpustakaan MINU Terate Puti tersebut sebagai pusat informasi, maka perpustakaan harus menyediakan bahan-bahan pustaka yang dapat membantu pengunjung maupun peserta didik untuk menambah semangat dalam menggunakan perpustakaan

Pengelolaan, dalam kamus besar bahasa indonesia memberikan pengertian bahwa pengelolaan berasal dari kata olah atau pengolahan, yang berarti proses, perbuatan, atau cara mengelola. Pengelolaan adalah kegiatan berbagai macam bahan koleksi yang diterima perpustakaan berupa buku, majalah, buletin, laporan, skripsi/tesis, terbitan pemerintah, surat kabar, atlas, dan sebagainya. Agar menjadi keadaan siap untuk diatur pada tempat-tempat tertentu disusun secara sistematis sesuai dengan sistem yang berlaku, dipergunakan oleh siapa saja yang memerlukan. (Sumardji,1995:11).
Dari pengertian pengelolaan tersebut di atas diketahui bahwa kegiatan pengelolaan bahan pustaka di perpustakaan sangat penting untuk mempermudah pemakai jasa perpustakaan menemukan bahan pustaka atau informasi. Secara singkat fungsi serta manfaat perpustakaan pada umumnya sebagai berikut: 1) Perpustakaan sebagai sarana penunjang pendidikan; 2) Perpustakaan merupakan sumber pembinaan kurikulum; 3) Perpustakaan sebagai sarana proses belajar/mengajar; perpustakaan sebagai sarana penanaman dan pembinaan minat baca; 4) perpustakaan dan penanaman disiplin; 5) Perpustakaan dan rekreasi; 6) perpustakaan dan penelitian; 8) perpustakaan dan calon guru

Secara etimologi, pelayanan adalah suatu perihal atau usaha untuk melayani kebutuhan orang lain dengan memperoleh imbalan atau jasa. Pelayanan perpustakaan adalah seluruh kegiatan penyampaian bantuan kepada pemakai melalui berbagai fasilitas, aturan atau cara tertentu pada sebuah perpustakaan, agar seluruh koleksi perpustakaan dapat dimanfaatkan semaksimal mungkin (Departemen Pendidikan dan Kebudayaan,1996: 34).

Pelayanan merupakan bagian integral yang tidak dapat dipisahkan dari sebuah perpustakaan. Aspek pelayanan ini memuat berbagai hal yang sangat mempengaruhi kesuksesan perpustakaan sebagai lembaga jasa dalam lingkungan masyarakat. Menurut Soejono Trimo (1992: 5) untuk memberikan pelayanan semaksimal mungkin kepada pemustaka setidaknya ada empat hal yang mendasar, yaitu: gedung, koleksi, pustakawan, dan pemakai

Pelayanan perpustakaan merupakan ujung tombak jasa perpustakaan karena bagian inilah pertama kali berhubungan dengan pemustaka. pelayanan perpustakaan bertujuan untuk membantu pemakai yang ada di perpustakaan dan sebaliknya perpustakaan harus melayani kebutuhan para pemustaka secara maksimal karena layanan perpustakaan baru terasa manfaatnya bila informasi yang diberikan sesuai dengan kebutuhan pemustaka. Seperti yang dikemukakan oleh Muchydin. "kegiatan pelayanan perpustakaan merupakan suatu sub unit kerja di perpustakaan yang mempunyai tugas pokok untuk memberikan layanan, bimbingan, informasi dan pengarahan berikut 
pengadaannya agar para pemustaka dapat memperoleh kesempatan dan fasilitas semaksimal mungkin untuk menelusuri dan mempelajari informasi yang diperlukan sesuai dengan kebutuhan" (Ase. S Muchydin. Pelayanan pemakai perpustakaan. 1980: 3). Dalam Pasal 14 ayat 3 tentang layanan perpustakaan disebutkan bahwa "setiap perpustakaan mengembangkan layanan perpustakaan sesuai dengan kemajuan teknologi informasi dan komunikasi".

Model layanan perpustakaan terbagi atas tiga, yakni pertama layanan terbuka yang merupakan model layanan dengan memberi kebebasan kepada pemustaka untuk melakukan penelusuran secara langsung ke rakrak koleksi perpustakaan. Model layanan terbuka biasanya dilakukan dengan pertimbangan kemandirian pemustaka yang telah cukup paham dengan sistem penelusuran informasi di perpustakaan, baik melalui pendidikan pemustaka maupun yang terlatih secara otodidak dengan seringnya pemustaka mengunjungi sebuah perpustakaan. Model yang kedua adalah layanan yang terbatas. Awalnya layanan ini lebih identik dengan istilah layanan tertutup, namun setelah menyadari bahwa sebuah layanan tertutup juga dapat berkonotasi sebagai layanan yang sudah tutup atau tidak ada layanan, maka istilah tertutup diganti dengan kata terbatas. Sesuai degan namanya, layanan terbatas merupakan layanan yang diberikan secara terbatas pula. Hal ini dilakukan dengan berbagai pertimbangan, antara lain untuk menjaga kelestarian koleksi sebab perpustakaan yang menerapkan model layanan terbatas umumnya adalah perpustakaanperpustakaan khusus dengan koleksi yang khusus pula, misalnya perpustakaan departemen, instansi, penelitian, militer dan beberapa perpustakaan-perpustakaan dengan koleksikoleksi khusus lainnya. Model ketiga adalah layanan kompilasi. Layanan ini merupakan gabungan antara layanan terbuka dengan layanan terbatas. Layanan ini diberikan dengan pertimbangan heterogenitas pemustaka. Bervariasinya tingkat pendidikan dan persepsi pemustaka terhadap sistem penelusuran informasi perpustakaan menyebabkan hampir seluruh perpustakaan umum, baik pusat maupun daerah.
Secara umum layanan yang akan didapatkan oleh para pemustaka di perpustakaan, antara lain: 1) Layanan peminjaman, yakni layanan yang diberikan oleh perpustakaan untuk memberi kemudahan dan waktu yang lebih banyak bagi para pemustaka untuk menyelesaikan bacaannya dengan cara meminjam. 2) Layanan ruang baca, yakni layanan penyediaan ruang baca bagi pemustaka yang memilih untuk menelusur dan membaca secara langsung informasi yang dibutuhkan di ruang baca perpustakaan. 3) Layanan konseling, yakni layanan interaktif antara pemustaka dengan pustakawan yang membutuhkan bimbingan tata cara pemanfaatan layanan perpustakaan secara baik dan benar. 4) Layanan informasi, yakni layanan penyediaan sumbersumber informasi, baik primer maupun sekunder (Muh. Quraisy Mathar, 2012: 142).

Hakikat layanan perpustakaan berimplikasi terhadap kegiatan perpustakaan itu sendiri. Kegiatan yang dilakukan oleh pihak pengelola perpustakaan selanjutnya perlu mempertimbangkan asas layanan sebagaimana yang dikemukakan Darmono (2001) berikut ini: 1) Berorientasi kepada kebutuhan dan kepentingan pemakai perpustakaan; 2) Diberikan atas dasar keseragaman, keadilan, merata, dan memandang pemakai perpustakaan sebagai suatu kesatuan yang menyeluruh dan tidak dipandang secara individu; 3) Layanan perpustakaan dilandasi dengan tata aturan yang jelas; 4) Layanan dilaksanakan dengan mempertimbangkan faktor kecepatan, ketepatan dan kemudahan dengan didukung oleh administrasi yang baik.

Hal di atas merupakan dasar bagi pengelola perpustakaan dalam mempersiapkan kegiatan layanan yang berorietasi kepada pemustaka agar koleksi yang dapat dimanfaatkan oleh para pemustaka secara maksimal. Ada 2 (dua) jenis sistem layanan yang lazim digunakan di beberapa perpustakaan, yakni sistem layanan terbuka, dan sistem layanan tertutup. Sistem layanan terbuka adalah suatu sistem yang dijalankan dimana seorang pemustaka dapat langsung ke rak koleksi untuk mengakses atau memilih koleksi yang dibutuhkan. Keuntungan layanan ini adalah kebebasan pihak pemustaka dalam melakukan penelusuran secara langsung, 
biasanya dilakukan dengan tujuan agar pemustaka dapat secara bebas memilh bahan yang cocok untuk dikehendaki (Hyman, 1927). Sementara kelemahannya adalah dalam hal kontrol terhadap pemustaka itu sendiri ketika melakukan suatu proses penelusuran.

Sistem layanan tertutup merupakan suatu sistem yang dijalankan dimana seorang pemustaka tidak dapat langsung ke rak koleksi untuk mengakses atau memilih koleksi yang dibutuhkan. Namun layanan ini memiliki keuntungan dari sisi kemudahan kontrol terhadap koleksi dan pemustakanya.

Ada beberapa jenis layanan dalam dunia perpustakaan. Darmono (2001) mengemukakan mengenai jenis layanan perpustakaan sebagai berikut: layanan peminjaman bahan pustaka (sirkulasi), layanan referensi, layanan ruang baca, layanan audio visual (AV), layanan jasa dokumentasi (konsultasi), layanan terjemahan, layanan jasa silang layang, layanan pembedelan dan perbaikan buku.

Selanjutnya oleh Gaspersz (2002) dikemukakan mengenai sejumlah kriteria yang mencirikan pelayanan sekaligus membedakannya dengan barang, yaitu: 1) Pelayanan merupakan output tak berbentuk; 2) Pelayanan merupakan output variabel, tidak berstandar; 3) Pelayanan tidak dapat disimpan dalam inventori, tetapi dapat dikonsumsi dalam produksi; 4) Terdapat hubungan langsung yang erat dengan pelanggan melalui proses pelayanan; 5) Pelanggan berpartisipasi dalam proses memberikan pelayanan; 6) Keterampilan personel "diserahkan" atau diberikan secara langsung kepada pelanggan; 7) Pelayanan tidak dapat diproduksi secara massal; 8) Membutuhkan pertimbangan pribadi yang tinggi dari individu yang memberikan pelayanan; 9) Perusahaan jasa pada umumnya bersifat padat karya; 10) Fasilitas pelayanan berada dekat lokasi pelanggan; 11) Pengukuran efektivitas pelayanan bersifat subjektif ; 12) Pengendalian kualitas terutama dibatasi pada pengendalian proses; 13) Penetapan harga adalah lebih sulit.

Pengelolaan adalah kegiatan berbagai macam bahan koleksi yang diterima perpustakaan berupa buku, majalah, buletin, laporan, skripsi/tesis, terbitan pemerintah, surat kabar, atlas, dan sebagainya. Agar menjadi keadaan siap untuk diatur pada tempat-tempat tertentu disusun secara sistematis sesuai dengan sistem yang berlaku, dipergunakan oleh siapa saja yang memerlukan. (Sumardji,1995:11).

Dari pengertian pengelolaan tersebut di atas diketahui bahwa kegiatan pengolahan bahan pustaka di perpustakaan sangat penting untuk mempermudah pemakai jasa perpustakaan menemukan bahan pustaka atau informasi. Tujuan pengelolaan atau pengaturan bahanbahan pustaka tidak lain adalah agar dapat digunakan dengan sebaik-baiknya oleh pemustakanya.

Lebih jauh lagi adalah bagaimana agar dengan pengaturan tersebut dapat membangkitkan minat setiap pemakai untuk selalu mengunjungi perpustakaan. Dengan demikian perpustakaan tersebut akan selalu digunakan oleh pemustaka.

Pelayanan perpustakaan merupakan proses rangkaian aktifitas yang berlangsung tanpa henti. Proses dalam hal ini diawali dengan pengadaan sampel pada penyajian bahan pustaka bagi pemakai jasa perpustakaan. Pengguna jasa perpustakaan atau pengunjung diharapkan memperoleh kepuasan serta rasa nyaman dalam menggunakan jasa perpustakaan. Layanan adalah penilaian terhadap proses layanan dalam memenuhi tugasnya atau didefinisikan sebagai seberapa baik suatu layanan (white, 1995). Mutu layanan merupakan derajat sejauh mana perbedaan antara kenyataan dan harapan pemakai atas layanan yang mereka terima dan dapat diketahui dengan cara membandingkan antara persepsi pemakai atas layanan yang mereka terima dengan layanan yang mereka harapkan (Jebarus, 1997).

Pengukuran mutu layanan dapat dilakukan dengan dua perspektif yang berbeda, yaitu perspektif internal organisasi dan perspektif pemakai, dimana ukuran mutu layanan dari perspektif internal organisasi dianggap sebagai metode pengukuran yang tradisional (Hebert, 1994).

\section{METODE PENELITIAN}

Adapun metode yang penulis gunakan untuk mengumpulkan data dan informasi adalah Observasi, yaitu mengadakan pengamatan langsung di lokasi kegiatan. Observasi adalah 
pengumpulan data yang dilakukan melalui pengamatan untuk mendapatkan informasi tentang obyek penelitian.

Pengolahan data adalah merupakan kegiatan pengelompokan data berdasarkan variabel sehingga dapat dengan mudah di baca dan dimengerti oleh peneliti. Adapun metode pengolahan yang digunakan yaitu metode kuantitatif. Teknik pengolahan dan analisis data dalam kegiatan ini menggunakan metode penelitian kuantitatif. Data yang di peroleh dikumpul, dikelompokan, kemudian, disajikan dalam bentuk deskripsi kuantitatif. Data/hasil yang diperoleh (output aktual) dibagi dengan nilai target.

\section{HASIL PENELITIAN DAN PEMBAHASAN}

Banyak inovasi yang dilakukan oleh MINU Trate Putri Gresik saat ini dan banyak juga prestasi yang diraih oleh Madrasah dalam hal ini pada tahun 2017 sebagai Juara 1 Tingkat Kabupaten Perpustakaan. Hal ini yang memacu dan memotivasi madrasah mengambil salah satu program Gerakan Ayo Membangun Madrasah Literasi yaitu melalui Literasi perpustakaan

Visi "Terwujudnya Madrasah yang bersih, trampil, disiplin dan berprestasi menuju Madrasah Berstandar Nasional dan Internasional berbasis pada Pesantren"

Misi: menciptakan lingkungan Madrasah yang bersih, menciptakan SDM yang terampil dalam penguasaan teknologi canggih terutama ICT, menumbuhkembangkan semangat berprestasi dalam bidang akademis dan non akademis kepada seluruh warga madrasah, menyelenggarakan pembelajaran yang inovatif melalui lingkungan madrasah sebagai sumber belajar, mengembangkan aktifitas keagamaan yang berwawasan Ahlussunah Wal jama'ah dalam rangka peningkatan Iman dan taqwa.

Pengertian tujuan madrasah adalah tahapan atau langkah untuk mewujudkan visi dalam jangka waktu tertentu, dengan kata lain tujuan merupakan "APA" yang akan dicapai/dihasilkan oleh madrasah yang bersangkutan dan "KAPAN" tujuan itu akan tercapai.

Tujuan dikaitkan dengan jangka waktu 3-5 tahun, jika visi merupakan gambaran madrasah secara utuh atau ideal, maka tujuan yang ingin dicapai dalam jangka waktu 3 tahun mungkin belum seideal visi atau belum selengkap visi dengan kata lain tujuan itu dapat terwujud dari sebagian visi yang kita buat.

Madarasah Ibtidaiyah sebagai salah satu lembaga pendidikan formal bercirikhas agama Islam senyatanya memiliki keunggulan dalam membangun komitmen keagamaan yang jelas dan memiliki prospek yang sangat baik. Dalam rangka menjaga eksistensi dan kualitas madrasah. Sehingga perlu adanya inovasi yang dilakukan oleh madrasah dengan menentukan program program unggulan sesuai potensi madrasah.

Sesuai dengan kearifan lokal dan kondisi madrasah, maka Prioritas program unggulan yang dijalankan MINU Trate Putri dalam meningkatkan mutu dan daya saing global melalui pengembangan karakter, literasi, kompetensi adalah ingin mewujudkan Madrasah Literasi. Pelaksanaan program ini dimulai dengan upaya membenahi ruang perpustakaan dan pojok baca di lingkungan sekolah. Selanjutnya dibentuk tim "Gelem" dalam rangka menyusun program.

Madrasah Literasi adalah madrasah yang mengembangkan budaya dan lingkungan melek teknologi, melek informasi, berpikir kritis, melek literasi dasar, literasi dan peka terhadap lingkungan. Madrasah mampu membangun kampung-kampung (gazebo) baca di lingkungan madrasah, pojok baca, kantin literasi, budaya orasi ilmiah, budaya tulis, dan budaya publikasi ilmiah. Termasuk tata kelola perpustakaan.

Tujuan Madrasah Literasi MINU Trate Putri antara lain: menumbuhkembangkan budaya literasi di madrasah, meningkatkan kapasitas warga dan lingkungan Madrasai Literasi, menjadikan madrasah sebagai taman belajar yang menyenangkan dan ramah anak agar warga madrasah mampu mengelola pengetahuan, menjaga keberlanjutan pembelajaran dengan menghadirkan beragam buku bacaan dan mewadahi berbagai strategi membaca.

Upaya yang ditempuh untuk mewujudkan Madrasah Literasi berupa; 1) Pembiasaan membaca peserta didik. Pembiasaan ini dilakukan dengan 15 menit membaca (guru membacakan buku dan warga sekolah membacakan dalam hati, yang disesuaikan dengan konteks madrasah), jika sudah terbentuk, 
selanjutnya diarahkan ke tahap pengembangan dan pembelajaran (dengan tagihan), dengan adanya panggung ekspresi, siswa mempresentasikan di atas panggung dari hasil apa yang dibaca dari buku sehingga bisa mendorong terjadinya literasi aktif-produktif pada diri siswa, resensi merupakan salah satu kegiatan siswa dalam pembelajaran di kelas, untuk tetap terus-menerus dan berkembang maka dibuat jadwal serta dilakukan asesmen agar dampak program ini dirasakan oleh warga sekolah khususnya dan masyarakat sekitar pada umumnya; 2) Program pembelajaran tematik perpustakaan (Tema P), dengan program ini pembelajaran tematik dilakukan didalam perpustakaan; 3) Program kegiatan muhadhoro, ajang kreasi siswa dalam mengasah kemampuan dan bakat siswa; 4) Promosi literasi menumbuhkembangkan minat baca sejak usia dini, yaitu mengundang sekolah-sekolah TK/Paud untuk berkunjung ke perpustakaan.; 5Program lomba sudut baca kelas dan lomba poster literasi adalah lomba antar kelas, koleksi sudut baca berasal dari buku pribadi siswa yang dibawah dari rumah masing-masing dan dilengkapi dengan poster berisikan motivasi/slogan sebagai wujud dukungan kegiatan literasi; 6) Program pelatihan jurnalistik dan penerbitan majalah merupakan kegiatan/bimbingan menulis bagi siswa untuk meliput dan mengumpulkan fakta-fakta peristiwa dari berbagai sumber kemudian menuliskan dalam sebuah berita jadi; 7) Lomba menulis cerpen, merupakan salah satu karya sastra yang bersifat fiktif yang menggambarkan suatu peristiwa yang dialami dan diringkas atau imajinasi siswa yang disertai konflik dengan penyelesaian masalah yang ada; 8) Program pawai literasi merupakan program pawai yang dilakukan siswa dengan kelengkapan posterposter kampanye sebagai motivasi/slogan literasi; 9) Untuk menunjang program literasi, maka dibutuhkan upaya pembenahan/pelebaran

ruang perpustakaan karena perpustakaan sebagai jantung sekolah yang mempunyai peranan penting dalam manajemen pengelolaan

pengetahuan dan sumber belajar. Serta pembuatan gubuk baca dan galeri di lingkungan madrasah sehingga bisa membuat siswa menjadi nyaman dalam membaca
Perpustakaan Bustanul Ilmi MINU Trate Putri Gresik adalah perpustkaan yang dapat melayani kebutuhan informasi yang berbasis koleksi perpustkaan. Buku-buku yang mempunyai nilai pendidikan keagamaan dan koleksi karya tulis atau karya cetak guna memenuhi kebutuhan pendidikan, penelitian, informasi, dan rekreasi bagi pemustaka. Jumlah koleksi Buku yang terdapat dalam perputakaan Balai Diklat MINU Trate Putri Gresik 2.970 Judul

Buku, 6.420 eksemplar. Gedung perpustakaan MINU Trte Putri Gresik terdapat dalam komplek MINU Trate Gresik tepatnya berada di bagian depan komplek dekat dengan mushollah MINU Trate Putri Gresik. Perpustakaan ini memiliki luas $72 \mathrm{M}^{2}$. Di dalam perpustakaan terdapat ruang koleksi, ruang baca, dan ruang pustakawan.

Pelayanan Perpustakaan Bustanul Ilmi MINU Trate Putri Gresik dibuka mulai pukul 06.45 sampai dengan 15.30. untuk tenaga perpustkaan sendiri terdiri dari 2 pegawai yaitu Pegawai Jabatan Fungsional Tertentu dan Jabatan Fungsional Umum.

Dalam pengelolahan perpustakaan yang ada di MINU Trate Putri Gresik dimulai dengan menerima dan memeriksa bahan pustaka yang dicatat dalam Daftar pustaka, bukti tanda terima. Setelah bahan pustaka diterima maka pustakawan menyetempel bahan pustaka.

Setelah bahan pustaka diterima dan distempel, bahan pustaka dikumpulkan dalam 6 hari atau seminggu. Dalam pengumpulkan bahan pustaka, pustakawan mengklarifikasi bahan pustaka yang sesuai dengan kreteria yang telah ditentukan kemudian mengkatalogisasi bahan pustaka. Proses mengkatalogisasikan, pustakawan juga memberikan kantong dan buku dan lembar peminjaman untuk dicatat bahan pustaka di buku induk. Pencatatan dalam buku induk ini dilakukan dengan 2 cara yaitu secara manual dan secara elektronik. Secara manual ditulis dalam Buku Induk dan secara elektronik disimpan di File komputer.

Pada proses akhir dalam pengelolahan bahan pustaka, bahan pustaka ditata di rak yang sudah disediakan. 


\section{KESIMPULAN}

Dalam pengelolahan bahan pustaka yang dilaksanakan di MINU Terate Putri sudah menggunakan Standar dalam prosedur yang dapat di jalankan sesuai dengan rencana, pelaksanaan, pengawasan sehingga dalam pelayanan pengelohan perpustakaan sudah efektif bagi keberadaan Perpustakaan Bustanul Ilmi di MINU Terate Putri Gresik.

\section{DAFTAR PUSTAKA}

A.Idris kamah. 2008. Perpustakaan sekolah (Pembinaan Perpustakaan dan Minat Baca), Makassar: Yayasan Pencerdasan Insani.

Amstrong, Barbara.1994.Costumer Focus: Obtaining Costumer Input. The Australian Library Journal.

Ase. S.Muchydin.1980. Pelayanan Pemakai Perpustakaan:Jakarta : Djambatan.

Daan Suganda.1986.Kepemimpinan Dalam Administrasi, cet 2. Bandung:Sinar Baru.

Darmono. 2001. Manajemen dan Tata Kerja Perpustakaan Sekolah, Jakarta : Grasindo.

Departemen Pendidikan dan Kebudayaan.1996.Pedoman

Penyelenggara Perpustakaan Umum: Jakarta: SN

Handayaningrat.1985.Pengantar Studi/Umum Administrasi dan Manajemen. Jakarta : Gunung Agung.

Hebert, Francoise. 1994. Service Quality: Unobtrusive Investigation of Inter Library

Hildawati Almah. 2012.Pemilihan \& Pengembangan Koleksi Perpustakaan, Makassar: Alauddin University Press.

Hyman, Richard joseph. 1972. Acces to Library Collection: an Inquiry Into Validity of the Direct Shelf with Special Reference to Browsing. New York: Scacecrow.

Lasa Hs. 1995. Jenis-jenis Pelayanan dan Informasi Perpustakaan, Yogyakarta: UGM, 1995.

Loans in Large Publik Libraries in Canada. Library and Information Scinece Research.
Mahmud Gandhi Andess.1997.Pelayanan Bahan Pustaka,cet.1 Jakarta: Universitas terbuka, DEKDIKBUD.

Mathar, Muh Quraisy.2012.Manajemen dan Organisasi Perpustakaan, Makassar: Alauddin University Press.

Noerhayati S.I. 1987. Pengelolaan Perpustakaan,Bandung : Alumni, Jilid 1. 70 Soewarno

Suharsimi Arikunto.1989.Prosedur Penelitian Suatu Pendekatan Praktis, Jakarta: Bulan Bintang.

Sulistyo Basuki. 2003. Pengantar Ilmu Perpustakaan, Jakarta: Grasindo. Sumardji. $1995 . \quad$ Mengelolah Perpustakaan, Yogyakarta: Kanisius.

Sutrisno Hadi.1984.Pengantar Statistik $l l$, Yogyakarta : Yayasan Penerbit UGM, jld 2.

Yuyu Yulia. 1993. Janti G.Sujana Henny Widarti, Pengadaan Bahan Pustaka, Jakarta: Universitas Terbuka. 